\title{
The Mediation Role of Personal Meaning Profile in The Relationship Between Resilience Capacity and Meaning in Life*
}

\author{
Tuğba Seda Çolak* \\ Duzce University, Department of Psychological Counselling, Duzce, Turkey \\ ORCID: 0000- 0002-7219-1999 \\ Neslihan Arıcı-Özcan \\ Istanbul Medeniyet University, Department of Social Services, Istanbul, Turkey \\ ORCID: 0000-0002-6169-1445
}

\section{Adem Peker}

Atatürk University, Department of Psychological Counselling, Erzurum, Turkey ORCID:0000-0002-3594-9166

\begin{tabular}{|c|c|}
\hline Article history & The main purpose of this study is to examine the mediation role of \\
\hline $\begin{array}{l}\text { Received: } \\
24.05 .2020\end{array}$ & $\begin{array}{l}\text { personal meaning profile in the relationship between resilience capacity } \\
\text { and meaning in life. Data has been collected from } 371 \text { college students }\end{array}$ \\
\hline $\begin{array}{l}\text { Received in revised form: } \\
21.12 .2020\end{array}$ & $\begin{array}{l}\text { using Resilience, Personal Meaning Profile and Meaning in Life Scales. } \\
\text { Jamovi 1.1.4 statistical program has been used for the analysis of the } \\
\text { data. In the study, it has been observed that there exist meaningful }\end{array}$ \\
\hline $\begin{array}{l}\text { Accepted: } \\
08.02 .2021\end{array}$ & $\begin{array}{l}\text { relationships between the sub-dimensions of the personal meaning } \\
\text { profile and resilience besides meaning in life. Results show that there is }\end{array}$ \\
\hline Key words: & a meaningful and positive relation between resilience and meaning in \\
\hline $\begin{array}{l}\text { Resilience; } \\
\text { Personal meaning; } \\
\text { Purpose of life; } \\
\text { Meaning in life }\end{array}$ & $\begin{array}{l}\text { life. It has been also observed that there has been a positive relation } \\
\text { between meaning in life and the achievement, relationship, self- } \\
\text { transcendence, self-acceptance, intimacy, and fairness sub-dimensions of } \\
\text { the personal meaning profile. However, no meaningful relationship } \\
\text { between resilience and the religion sub-dimension of the personal } \\
\text { meaning profile has been found. Considering the findings of the research, } \\
\text { there is a significant mediation role of the personal meaning profile, } \\
\text { except for the religion and self-acceptance sub-dimensions, in the } \\
\text { relationship between the resilience capacity and the meaning in life. All } \\
\text { findings have been discussed in terms of literature and the suggestion for } \\
\text { further studies has been made. }\end{array}$ \\
\hline
\end{tabular}

\section{Introduction}

\section{Meaning in Life}

Meaning is a concept that is central to theories about happiness (Lightsey, 2006). Human being is the only creature that life makes any sense to him/her (Emmons, 2002, 2005). Therefore, what life means has been searched for and questioned by a number of philosophers

\footnotetext{
* Correspondency: tugbacolak@duzce.edu.tr
} 
since the ancient times (Evans, 2012; Sezer, 2012). In modern psychology, Adler is the first person to define the meaning in life and explains that "human beings live in the realm of meanings' (1962, p. 1). Many psychologists such as Frankl (1963), Maddi (1970), Yalom (1980), Thompson and Janigian (1988), and Baumeister (1991) explain the concept, meaning in life, from different perspectives. Frankl (1963) emphasizes this concept within the theory of Logotherapy and states that meaning is vital for a human being to comprehend, motivate and enact his/her life within a community. According to Logotherapy, the main motivating force in life is the desire to find meaning in life (Budak, 2003). When this desire is not met, the existential vacuum that causes a spiritual crisis occurs. It also causes such symptoms as inner emptiness, emotionlessness, irrational fears, pessimistic thoughts, and a sense of meaningless (Graber, 2004).

Adolescence is a period when individuals start to feel existential vacuum, and when the quest for meaning gets important for identity development (Fry, 1998). Especially during the transition between the ages of 18 and 25, individuals need to fulfill many developmental tasks and responsibilities (academic, economic, professional, personal, social) and cope with many challenges that come along with it (Arnett, 2007; Jekielek \& Brown, 2005). It is important for them to find meaning in life while dealing with those challenges (Fry, 1998; Heng, Fulmer, Blau \& Pereira, 2020; Wong \& Wong, 2012).

Among three types of values, the creative, experiential and attitudinal values which enable one to find meaning in life, attitudinal values are regarded as the most significant (Lukas, 1986). One's changing attitude and redirecting his/her spiritual energy in order to find meaning in life is a Logotherapeutic response given to pain. Especially when there is a negative experience, lack of meaning in life causes pain to turn into despair and self-harm. Frankl states that pain matures, enriches and strengthens mankind (Guttman, 2001). Similarly, Ameli and Dattilio (2013) claim that combining attitudinal preferences and discovery of meaning in situations where pain is inevitable cannot only help a counselee to tolerate and accept pain but also reduce the risk of depression, despair and suicide. At this point, resilience can be considered as a factor which effects and helps to increase meaning in life. By this way, concepts which protect mental health could be shed light on.

\section{Resilience}

Resilience has been conceptualized in many different ways in the literature (e.g., as a trait, a process, or an outcome), and more generally it refers to positive adaptation to adversity. Resilience can be defined as a measurable and modifiable mechanism involving individuals' awareness of their state or capacity to be strong, which lets them deal with stressful situations and use their available resources better, and it can be seen as self-sufficiency in a broad or general sense (Lightsey, 2006). Resilience is a dynamic process that includes positive adaptation (Iacoviello \& Charney, 2020; Luthar, Cicchetti \& Becker, 2000). Any challenge or threat activates two separate cognitive adaptation processes (Davis, Nolen-Hoeksema \& Larson, 1998; Janoff-Bulman \& Frantz, 1997). One of them is the comprehension of events considering the past time (Taylor, 2003; Joseph \& Linley, 2005) and the second one is searching for personal significance considering the present time (Helgeson, Reynolds \& Tomich, 2006; Tedeschi \& Calhoun, 1996). When an individual perceives threat with positive attributions in terms of past-time experiences and gives them personal meaning from various sources in his/her life, he/she will overcome them, besides benefiting from them (Kleber \& Brom, 1992). Thus, a meaning system, especially obtaining personal meaning from many sources, is very crucial to cope with difficulties and be resilient. It is especially very essential for a young adult to handle 
a problem and to develop his/her resilience as well as his/her mental health. In many studies (Kiang \& Fuligni, 2010; Pan et al., 2008), it has been noted that personal meaning has an important impact on one's ability to cope with difficulties and be resilient during young adulthood.

\section{Personal Meaning}

Finding meaning in life in accordance with an individual's attitudes is unique to his/her life, and this is a need inherent in human nature (Wong, 1997). Personal meaning has various definitions. According to Reker and Wong (1988), personal meaning is associated with meaning in life in terms of value, purpose, coherence and belief system. In another study, Wong (1989) has defined the same concept as a structured cognitive system based on individual values which can provide personal significance/value and satisfaction in life. The concept is accepted with an implicit meaning in an ideally meaningful life (Krok, 2015).

In accordance with the literature, personal meaning can be defined as one's attitude towards a problem status, rather than the stress caused by that problem or difficulty. An unhealthy attitude towards such a problem can block internal forces and push one into a passive role where $\mathrm{s} / \mathrm{he}$ feels like a desperate victim (Graber, 2004). For this reason, shaping attitudes is seen as one of the stages in Logotherapy, and it usually stimulates the desire for meaning in order to gain a deep and satisfying approach towards life. Thus, an individual is made aware of his or her own strengths (Marshall, 2009). In addition, it is important for an individual to determine his/her personal attitudes and know what he or she prioritizes as meaning in order to find meaning in challenges he or she has faces in life (Wong \& Wong, 2012).

\section{The Relationship between Variables and the Aim of the Study}

Various studies on resilience and meaning in life have been conducted so far (i.e. Grotberg, 2003; Masten \& Reed, 2002; Norman, 2000; Pan et al., 2008). Furthermore, O'connor (2003) has suggested that meaning can bridge between negative emotions caused by negative life events and positive emotions that arise through cognitive reconstruction. Barber (2008) has studied some youth living in war zones such as Bosnia and Gaza, and found that adolescents who have a meaning about their experiences are more resilient than adolescents that do not. Personal meaning is another important issue when resilience is taken into consideration. Wong and Wong (2012) state that resilience requires having a purpose in life, which is possible only through discovering personal meaning, which will make life worth living. The authors explained the concept of psychological resilience with an integrated model, taking meaning into focus. parallel to this, Schok, Kleber and Lensvelt-Mulders (2010) have found that resilience is strongly correlated with personal meanings in veteran populations. Moreover, Zeleskov-Doric, Hedrih and Doric (2012) have revealed that personal meaning mediates the relationship between resilience and vicarious trauma in therapists. In particular, the sub-dimension of the relationship with others predicts resilience at a significant level.

In those studies, the meaning in life is generally seen as the existence of meaning of life and the quest for meaning, as also suggested by Steger, Fraizer, Oishi and Kaler (2006). The personal meaning profile can also be used to measure the sense of meaning in life (i.e. Rathi \& Rastogi, 2007). However, identifying the sources of meaning which can lead one to meaning in life requires a clearer idea about how this topic can be handled. In this context, there are also studies dealing with meaning in life and personal meaning together, but as two separate subjects (Carrenon, Eisenbeck, Cangas, Garcia-Montes, Delvas, \& Maria, 2020). In a study, Krok (2015) has shown that there is a positive relation between personal meaning and meaning in 
life. Likewise, Schnell and Becker (2006) have examined meaningfulness and the sources of meaning with regard to personality traits and found that individuals possess certain sources of meaning which lead them to meaningfulness as a result of their personalities. A different study has demonstrated that meaning in life and having a distinct source of meaning in life have a negative correlation with burnout while they have a positive correlation with such feelings as personal achievement and competence (Krok, 2016; Park, Knott Williams, Clark, Williams, \& Schulz, 2020).

Meaning in life is an important factor for life quality. In this study, it is thought that resilience can provide the individual to give meaning in his/her life and his/her life difficulties. In the literature it is stated the resilient individuals more easily find meaning in life in difficult times (Brassai, Piko, \& Steger, 2011; Masten \& Reed, 2002; Masten, Cutuli, Herbers, \& Reed, 2009; Pan, Wong, Chan \& Loubert, 2008; Pan, 2011) and it is known that meaning comes from different sources (Pan, et al., 2008). Furthermore, many studies indicated individuals have different types of sources such as family, achievement, religion, intimacy, self- development and others. (Baaesler \& Oerter, 2003; Lin, 2001; Wong, 1998) but it is seen that no studies specifically showed which type of meaning sources help resilient individuals to give meaning in life. Therefore, there should be one or more mediator variables in the relation between resilience and meaning in life. Personal meaning profile gives concrete source of meaning (Wong, 1998); therefore it is also hypothesized that dimensions of personal meaning profile are mediators in the relation between resilience and meaning in life. To that end, the purpose of this study is to find out which of the sources of meaning possessed by individuals with resilience predict meaning in life. Within this context, personal sources of meaning have been examined with regard to ones' specific areas of meaning in life

\section{Method}

\section{Research Model}

In the research, correlational research model has been used to examine the mediation role of personal meaning profile between resilience and meaning in life. The following theoretical model, which has been developed to explain the relationship among resilience of college students and their levels of personal meaning and meaning in life, has been tested in this study.

\section{Participants}

The study group consisted of 371 students enrolled in the Faculty of Education at Erzurum Atatürk University, Düzce University and Istanbul Medipol University in Turkey in 2015-2016 academic year. Of all the participants, 227 (61.2\%) are female while $144(38.8 \%)$ are male. The ages of the participants ranged from 17 to $30.46 .2 \%$ of the participants are studying guidance and psychological counseling, while the major of $25.7 \%$ are social services, the major of $15.4 \%$ is psychology, and the major of $12.7 \%$ is social studies. G* Power program was used to calculate the sample size. In the program with linear multiple regression, .042 effect size, $5 \%$ margin of error, $95 \%$ confidence interval and minimum sample size for 2 independent variables was calculated as 371 . The output of the analysis is given in figure 1 . 


\begin{tabular}{|c|c|c|}
\hline \multicolumn{3}{|c|}{ F tests - Linear multiple regression: Fixed model, $R^{2}$ increase } \\
\hline Analysis: & A priori: Compute required so & size \\
\hline \multirow[t]{5}{*}{ Input: } & Effect size $\mathrm{f}^{2}$ & $=0.042$ \\
\hline & $\alpha$ err prob & $=0.05$ \\
\hline & Power ( $1-\beta$ err prob) & $=0.95$ \\
\hline & Number of tested predictors & $=2$ \\
\hline & Total number of predictors & $=8$ \\
\hline \multirow[t]{6}{*}{ Output: } & Noncentrality parameter $\lambda$ & $=15.5820000$ \\
\hline & Critical F & $=3.0206608$ \\
\hline & Numerator df & $=2$ \\
\hline & Denominator df & $=362$ \\
\hline & Total sample size & $=371$ \\
\hline & Actual power & $=0.9501286$ \\
\hline
\end{tabular}

Figure 1: $G *$ Power sample size calculation output

\section{Data Collection Tools}

Purpose in Life Scale: The scale has been developed to measure purpose in life by Steger et al. (2006) and adapted to Turkish by Demirbaş (2010). The scale has two subdimensions (searching meaning and belonging meaning) and 10 items. Internal consistency coefficient of the scale consisting of ten items has been found to be .86 . Test-retest reliability coefficient has been measured as .81. In this study, Cronbach alfa is found .78

Personal Meaning Profile: The scale developed by Wong (1998) consists of 57 items and 7 sub-dimensions (achievement, relationship, religion, self-transcendence, self-acceptance, intimacy, fairness) that aim to measure the perception of meaning in life. Goodness-of-fit indices of the scale, which have been adapted to Turkish by Akın, Düsünceli and Colak (2016), $\left(\mathrm{x}^{2}=3170.41, \mathrm{sd}=1518, \mathrm{p}=.00, \mathrm{x}^{2} / \mathrm{sd}=2.08, \mathrm{RMSEA}=.060, \mathrm{NFI}=.87, \mathrm{NNFI}=.92, \mathrm{CFI}=.93\right.$, $\mathrm{IFI}=.93, \mathrm{SRMR}=.07$ ) have been observed to be within acceptable limits. Factor loadings of the Turkish version of PMP ranged from .30 to .69 and Cronbach Alpha coefficient has been .93. The higher the score from PMP, the closer an individual to his/her ideal meaningful life. The main advantage of the scale is that it determines the sources of the quest for meaning. It shows specific areas in which an individual not only seeks meaning but also experiences it (Wong, 1998). In this study, Cronbach alfa has been found .94

Resilience Scale: The scale, which has been adapted to Turkish by Terzi (2006), has been originally developed by Wagnild and Young (1993) to determine the level of resilience, which is defined as a positive personality trait that strengthens individuals' adaptations. It is a 7-point Likert scale (7: strongly agree, 1: strongly disagree) including a total of 24 items. Cronbach Alpha reliability coefficient obtained in the adaptation study has been .82, and Pearson correlation coefficient has been found to be .84 . In this study, Cronbach alfa has been found as .96

\section{Analysis}

Data analysis was carried out with Jamovi (1.1.4) and SPSS 21.00 package programs. Jamovi is an " $R$ " based statistics software program. In this study, the relationship between variables has been examined with Pearson correlation coefficient. The Jamovi 1.1.4 program has been used for the mediating effect of the personal meaning profile between psychological resilience and the meaning in life. For mediating analysis, "GAMLJ: General analyzer for linear models module" in Jamovi program was used. This module makes mediation analysis regression-based. To determine whether descriptive values of the data have a normal 
distribution, the kurtosis and skewness coefficients have been calculated. The results are given in Table 1.

Table 1. Descriptive and normality values of the variables

\begin{tabular}{lcccc}
\hline Variables & Arithmetic mean & S.s & Skewness & Kurtosis \\
\hline Meaning in Life & 46.48 & 10.55 & .03 & -.75 \\
Resilience & 115.45 & 33.02 & -.85 & -.42 \\
Achievement & 86.34 & 14.24 & -.82 & .78 \\
Relationship & 51.93 & 6.72 & -.95 & 1.20 \\
Religion & 53.54 & 7.98 & -1.59 & 3.51 \\
Self-transcendence & 41.05 & 6.91 & -.65 & 1.15 \\
Self-acceptance & 31.63 & 4.88 & -.45 & .18 \\
Intimacy & 29.01 & 4.42 & -1.00 & 1.33 \\
Fairness & 19.20 & 3.99 & -.47 & .33 \\
\hline Total & & 371 & &
\end{tabular}

The fact that skewness and kurtosis values related to the sub-dimensions of meaning in life, resilience and personal meaning profile are between +3 and -3 they are considered as a measure of normal distribution of the data (Akbulut, 2010). It has been observed that the religion subdimension of the personal meaning profile does not meet the assumption of normality.

\section{Findings}

\section{Correlations between Variables}

The Pearson correlation coefficient values based on the measurements of meaning in life, resilience and the sub-dimensions of the personal meaning profile are given in Table 2.

Table 2. Inter-correlation values of variables

\begin{tabular}{|c|c|c|c|c|c|c|c|c|c|}
\hline & 1 & 2 & 3 & 4 & 5 & 6 & 7 & 8 & 9 \\
\hline 1. Meaning in Life & 1 & & & & & & & & \\
\hline 2. Resilience & $.24^{*}$ & 1 & & & & & & & \\
\hline 3. Achievement & $.30^{*}$ & $.27^{*}$ & 1 & & & & & & \\
\hline 4. Relationship & $.20^{*}$ & $.22^{*}$ & $.60^{*}$ & 1 & & & & & \\
\hline 5. Religion & $.21^{*}$ & .08 & $.37^{*}$ & $.46^{*}$ & 1 & & & & \\
\hline 6. Self-transcendence & $.33^{*}$ & $.15^{*}$ & $.72^{*}$ & $.57^{*}$ & $.45^{*}$ & 1 & & & \\
\hline 7. Self-acceptance & $.16^{*}$ & $.14^{*}$ & $.47^{*}$ & $.46^{*}$ & $.32^{*}$ & $.48^{*}$ & 1 & & \\
\hline 8. Intimacy & $.20^{*}$ & $.18^{*}$ & $.44^{*}$ & $.60^{*}$ & $.30^{*}$ & $.40^{*}$ & $.47^{*}$ & 1 & \\
\hline 9. Fairness & $.34^{*}$ & $.20^{*}$ & $.38^{*}$ & $.34^{*}$ & $.28^{*}$ & $.46^{*}$ & $.40^{*}$ & $.40^{*}$ & 1 \\
\hline $\mathrm{N}$ & & & & & 371 & & & & \\
\hline
\end{tabular}

$* \mathrm{p}<.05$

Table 2 shows that there is a positive correlation between the meaning in life and resilience, relationship, intimacy, religion and self-acceptance at a low level, and there are meaningful positive correlations between meaning in life and achievement, self-transcendence and fairness at a medium level. It can also be observed that there is a positive and low level meaningful relationship between meaning in life and resilience as well as the achievement, selftranscendence, self-acceptance, intimacy and fairness sub-dimensions of the personal meaning profile. However, no meaningful relationship between resilience and the religion sub- 
dimension of the personal meaning profile has been seen. Therefore, this variable has been not included in the analysis of the effectiveness of mediation model.

\section{Mediation Role of the Variables in the Personal Meaning Profile}

In this study, the mediating role of personal meaning profile between psychological resilience and meaning in life was examined. In addition to lower and upper confidence intervals, direct, indirect and total effect results of this process are presented in Tables 3, 4, 5, 6,7 and 8.

Table 3. Indirect effects of the achievement sub-dimension of the personal meaning profile

\begin{tabular}{|c|c|c|c|c|c|c|c|c|}
\hline \multirow[b]{2}{*}{ Type } & \multirow[b]{2}{*}{ Effect } & \multirow[b]{2}{*}{ Estimate } & \multirow[b]{2}{*}{ SE } & \multicolumn{2}{|c|}{ 95\% C.I. (a) } & \multirow[b]{2}{*}{$\beta$} & \multirow[b]{2}{*}{$\mathbf{z}$} & \multirow[b]{2}{*}{$p$} \\
\hline & & & & Lower & Upper & & & \\
\hline Indirect & $\begin{array}{l}* \mathrm{RS} \Rightarrow \mathrm{ac} \Rightarrow \\
\mathrm{MN}\end{array}$ & & .01 & .0087 & .0348 & .06 & 3.33 & $.001 *$ \\
\hline & $* \mathrm{RS} \Rightarrow \mathrm{ac}$ & .11 & .01 & .0657 & 1634 & .26 & 4.67 & $.001^{*}$ \\
\hline Component & $* \mathrm{ac} \Rightarrow \mathrm{MN}$ & .19 & .03 & .1155 & 2647 & .25 & 5.00 & $.001^{*}$ \\
\hline Direct & $* \mathrm{RS} \Rightarrow \mathrm{MN}$ & .06 & .01 & .0210 & 0874 & .16 & 3.17 & $.002 *$ \\
\hline Total & $* \mathrm{RS} \Rightarrow \mathrm{MN}$ & .07 & .01 & .0441 & .1075 & .23 & 4.69 & $.001^{*}$ \\
\hline
\end{tabular}

Table 4. Indirect effects of the relationship sub-dimension of the personal meaning profile

\begin{tabular}{|c|c|c|c|c|c|c|c|c|}
\hline \multirow[b]{2}{*}{ Type } & \multirow[b]{2}{*}{ Effect } & \multirow[b]{2}{*}{ Estimate } & \multirow[b]{2}{*}{ SE } & \multicolumn{2}{|c|}{ 95\% C.I. (a) } & \multirow[b]{2}{*}{ B } & \multirow[b]{2}{*}{$\mathbf{z}$} & \multirow[b]{2}{*}{$p$} \\
\hline & & & & Lower & Upper & & & \\
\hline Indirect & $\mathrm{RS} \Rightarrow \mathrm{r} \Rightarrow \mathrm{MN}$ & .01 & .01 & .0019 & .0196 & .03 & 2.45 & $.014 *$ \\
\hline \multirow[t]{2}{*}{ Component } & $\mathrm{RS} \Rightarrow \mathrm{r}$ & .04 & .01 & .0193 & .0673 & .21 & 3.59 & $.001 *$ \\
\hline & $r \Rightarrow \mathrm{MN}$ & .25 & .07 & 1066 & .3906 & .16 & 3.49 & $.001 *$ \\
\hline Direct & $\mathrm{RS} \Rightarrow \mathrm{MN}$ & .06 & .01 & .0334 & .0968 & .20 & 4.00 & $.001 *$ \\
\hline Total & $\mathrm{RS} \Rightarrow \mathrm{MN}$ & .07 & .01 & 等. & . 1075 & .23 & 4.69 & $.001 *$ \\
\hline $\begin{array}{l}* \mathrm{R} \\
* \mathrm{r}: \\
* \mathrm{M} \\
{ }^{*} \mathrm{p}<\end{array}$ & $\begin{array}{l}\text { Resilience } \\
\text { elationships } \\
\text { J: Meaning in } \\
5\end{array}$ & & & & & & & \\
\hline
\end{tabular}

Table 5. Indirect effects of the self-transcendence sub-dimension of the personal meaning profile

\begin{tabular}{|c|c|c|c|c|c|c|c|c|}
\hline \multirow[b]{2}{*}{ Type } & \multirow[b]{2}{*}{ Effect } & \multirow[b]{2}{*}{ Estimate } & \multirow[b]{2}{*}{ SE } & \multicolumn{2}{|c|}{ 95\% C.I. (a) } & \multirow[b]{2}{*}{ B } & \multirow[b]{2}{*}{$\mathbf{Z}$} & \multirow[b]{2}{*}{$p$} \\
\hline & & & & Lower & Upper & & & \\
\hline Indirect & $\mathrm{RS} \Rightarrow \mathrm{st} \Rightarrow \mathrm{MN}$ & .01 & .01 & .0023 & .0256 & .04 & 2.41 & $.016 *$ \\
\hline \multirow[t]{2}{*}{ Component } & $\mathrm{RS} \Rightarrow \mathrm{st}$ & .03 & .01 & .0079 & .0534 & .15 & 2.70 & $.007 *$ \\
\hline & $\mathrm{st} \Rightarrow \mathrm{MN}$ & .45 & .07 & .3163 & .5959 & .30 & 6.42 & $.001 *$ \\
\hline Direct & $\mathrm{RS} \Rightarrow \mathrm{MN}$ & .06 & .01 & .0324 & . 0916 & .19 & 4.08 & $.001 *$ \\
\hline Total & $\mathrm{RS} \Rightarrow \mathrm{MN}$ & .07 & .01 & .0441 & .1075 & .23 & 4.69 & $.001 *$ \\
\hline
\end{tabular}

* RS: Resilience

* st: Self-transcendence

$*$ MN: Meaning in Life

$* \mathrm{p}<.05$ 
Table 6. Indirect effects of the self-acceptance sub-dimension of the personal meaning profile

\begin{tabular}{|c|c|c|c|c|c|c|c|c|}
\hline \multirow[b]{2}{*}{ Type } & \multirow[b]{2}{*}{ Effect } & \multirow[b]{2}{*}{ Estimate } & \multirow[b]{2}{*}{ SE } & \multicolumn{2}{|c|}{$95 \%$ C.I. (a) } & \multirow[b]{2}{*}{ B } & \multirow[b]{2}{*}{$\mathbf{Z}$} & \multirow[b]{2}{*}{$p$} \\
\hline & & & & Lower & Upper & & & \\
\hline Indirect & $\mathrm{RS} \Rightarrow \mathrm{sa} \Rightarrow \mathrm{MN}$ & .01 & .01 & -.0010 & .0128 & .02 & 1.65 & .100 \\
\hline \multirow[t]{2}{*}{ Component } & $\mathrm{RS} \Rightarrow \mathrm{sa}$ & .02 & .01 & .0030 & .0373 & .14 & 2.33 & $.020 *$ \\
\hline & $\mathrm{sa} \Rightarrow \mathrm{MN}$ & .28 & .11 & .0640 & .5138 & .13 & 2.48 & $.013 *$ \\
\hline Direct & $\mathrm{RS} \Rightarrow \mathrm{MN}$ & .07 & .01 & .0386 & .1016 & .21 & 4.36 & $.001 *$ \\
\hline Total & $\mathrm{RS} \Rightarrow \mathrm{MN}$ & .07 & .01 & .0441 & .1075 & .23 & 4.69 & $.001^{*}$ \\
\hline
\end{tabular}

* RS: Resilience

* sa: Self- acceptance

* MN: Meaning in Life

$* \mathrm{p}<.05$

Table 7. Indirect effects of the intimacy sub-dimension of the personal meaning profile

\begin{tabular}{|c|c|c|c|c|c|c|c|c|}
\hline \multirow{2}{*}{ Type } & \multirow[b]{2}{*}{ Effect } & \multirow[b]{2}{*}{ Estimate } & \multirow[b]{2}{*}{ SE } & \multicolumn{2}{|c|}{ 95\% C.I. (a) } & \multirow[b]{2}{*}{ B } & \multirow[b]{2}{*}{$\mathbf{z}$} & \multirow[b]{2}{*}{$p$} \\
\hline & & & & Lower & Upper & & & \\
\hline \multirow{3}{*}{ Component } & $\mathrm{RS} \Rightarrow \mathrm{i} \Rightarrow \mathrm{MN}$ & .01 & .01 & .4044 & .0184 & .02 & 1.98 & $.048 *$ \\
\hline & $\mathrm{RS} \Rightarrow \mathrm{i}$ & .02 & .01 & .0100 & .0389 & .18 & 3.33 & $.001 *$ \\
\hline & $\mathrm{i} \Rightarrow \mathrm{MN}$ & .37 & .13 & .1328 & 6266 & .15 & 2.99 & $.003 *$ \\
\hline Direct & $\mathrm{RS} \Rightarrow \mathrm{MN}$ & .06 & .01 & .0350 & .0993 & .20 & 4.06 & $.001 *$ \\
\hline Total & $\mathrm{RS} \Rightarrow \mathrm{MN}$ & .07 & .01 & .0441 & .1075 & .23 & 4.69 & $.001 *$ \\
\hline \multicolumn{9}{|c|}{ * RS: Resilience } \\
\hline \multicolumn{9}{|c|}{ * i: Intimacy } \\
\hline \multicolumn{9}{|c|}{ * MN: Meaning in Life } \\
\hline$* \mathrm{p}<$ & & & & & & & & \\
\hline
\end{tabular}

Table 8. Indirect effects of the fairness sub-dimension of the personal meaning profile

\begin{tabular}{|c|c|c|c|c|c|c|c|c|}
\hline \multirow[b]{2}{*}{ Type } & \multirow[b]{2}{*}{ Effect } & \multirow[b]{2}{*}{ Estimate } & \multirow[b]{2}{*}{ SE } & \multicolumn{2}{|c|}{ 95\% C.I. (a) } & \multirow[b]{2}{*}{$\beta$} & \multirow[b]{2}{*}{$\mathbf{Z}$} & \multirow[b]{2}{*}{$p$} \\
\hline & & & & Lower & Upper & & & \\
\hline Indirect & $\mathrm{RS} \Rightarrow \mathrm{f} \Rightarrow \mathrm{MN}$ & .02 & .01 & .0062 & .0313 & .06 & 3.01 & $.003 *$ \\
\hline \multirow[t]{2}{*}{ Component } & $\mathrm{RS} \Rightarrow \mathrm{f}$ & .02 & .01 & .0104 & .0360 & .19 & 3.62 & $.001 *$ \\
\hline & $\mathrm{f} \Rightarrow \mathrm{MN}$ & .81 & .12 & .5667 & 1.052 & .30 & 6.57 & $.001 *$ \\
\hline Direct & $\mathrm{RS} \Rightarrow \mathrm{MN}$ & .06 & .01 & .0267 & .0873 & .18 & 3.67 & $.001 *$ \\
\hline Total & $\mathrm{RS} \Rightarrow \mathrm{MN}$ & .07 & .01 & .0441 & .1075 & .23 & 4.69 & $.001 *$ \\
\hline
\end{tabular}

*RS: Resilience

* f: Fairness

* MN: Meaning in Life

$* \mathrm{p}<.05$

The results given in Tables 3, 4, 5, 7, and 8 indicate that achievement, relationship, selftranscendence, intimacy and fairness sub-dimensions of the personal meaning profile have a mediation role in the relationship between resilience and meaning in life. In other words, it can be said that personal meaning has an important effect on the relationship between resilience and meaning in life in a general sense. Since the upper and lower limits of the confidence intervals of the indirect effects of the model do not contain zero, its mediation role can be said to be meaningful. However, it has been observed that the self-acceptance sub-dimension does not have a mediation role in the relationship between resilience and meaning in life (Table 6).

\section{Discussion}

In this study, the role of personal meaning as a mediator in the relationship between resilience and meaning in life has been examined, and it has been found that except for selfacceptance and religion, all sub-dimensions of personal meaning profile determined by Wong 
(1998) have a mediation role in the relationship between psychological resilience and the meaning in life.

According to the initial conclusion of the current study, there are meaningful relationships between the resilience and meaning in life. The findings of many other studies suggest that there is a meaningful relationship between the meaning in life and resilience, (i.e. Grotberg, 2003; Heng et al., 2020; Masten \& Reed, 2002; Norman, 2000; Pan et al., 2008) and are consistent with the findings of this study. According to Kim, Lee, Yu, Lee and Ping (2005), having a high level of meaning in life is related both to effective coping strategies and psychological resilience. All three variables have positive relations. It means being resilient is relational with having meaning in life.

This study has revealed that there is a meaningful relationship between resilience and all the other sub-dimensions of personal meaning (achievement, relationship, self-transcendence, selfacceptance, intimacy, and fairness), except for religion. Wong and Wong (2012) have stated that in order for an individual to have the strength to show resilience/to be psychologically resilient in the face of difficulties, s/he must discover his/her personal meaning, which makes life worth living. In addition, there are a number of other studies indicating a relationship between resilience and personal meaning, parallel to the finding of this study (Schok et al., 2010; Zeleskov-Doric et al., 2012; Wexler, DiFluvio \& Burke, 2009). However, no meaningful relationship between resilience and the religion dimension of the personal meaning profile has been seen. Although there are studies suggesting that there is a meaningful positive relationship between religious resilience and resilience in general (i.e, Batan \& Ayten, 2015; Erdoğan, 2015; Kasen, Wickramaratne, Gameroff \& Weissman, 2011), there are also other studies showing that this relationship gets weaker as one's level of age and education level increase (i.e. Uysal, Göktepe, Karagöz \& İlerisoy, 2017). This may be the reason why the participants (i.e., young adults studying at university) did not prioritize religion as a strategy while coping with the difficulties during the transition from late adolescence to adulthood.

In addition, the study has also revealed that there is a positive meaningful relationship between meaning in life and personal meaning. As also supported by a body of research (e.g., Krok, 2015, 2016; Schnell \& Becker, 2006), the meaning in life can be regarded as a factor associated with an individual's quest for personal meaning since they complement each other. In this context, this study has demonstrated a meaningful relationship between the meaning in life and all the dimensions of personal meaning.

Another finding of this research is that personal meaning has a mediator role in the relationship between resilience and meaning in life. Similarly, in a number of studies, it is stated that resilience has an important role in the facilitation of? the meaning in life (Grotberg, 2003; Kim et al., 2005; Masten \& Reed, 2002; Norman, 2000; Pan, 2011; Pan et al., 2008). However, as Emmons (2005) points out, an individual's being knowledgeable about his/her goals makes $\mathrm{him} / \mathrm{her}$ wiser. In this context, many studies in the literature suggest that knowing one's sources of personal meaning is important for processes protecting his/her mental health and being resilient (i.e. Schnell \& Becker, 2006; Zeleskov-Doric et al., 2012), which support the finding of this current study.

Achievement mediates the relationship between resilience and meaning in life. It can be seen as a feeling that arises as a result of reaching a goal. According to the current research findings, when resilient individuals fulfill or achieve something in their lives, they feel a sense of meaning in life. According to Lightsey (2006), resilience can be considered as self-efficacy. By 
taking this definition into consideration, it can be said that achievement is an important source for individuals in order to overcome their problems by believing in themselves when they encounter negative situations. Furthermore, the sense of self-sufficiency built through mastery experiences (Bandura, 1999) is an important factor in personality development. According to Bandura (2010), when individuals do not believe that they can produce a desired effect, they find it difficult to persevere in the face of difficulties. In addition, another study by Schnell and Becker (2006) has revealed that achievement has a significant role in the relationship between taking responsibility and meaning in life. Achievement can be said to support individuals while they are fulfilling their responsibilities by believing more in themselves after a resiliency gaining process, and thus it positively affects their level of meaning in life.

The relationship between resilience and meaning in life is mediated by relationships subdimension of personal meaning. For individuals with high levels of resiliency, the more meaningful the relationships and intimacy become in their lives, the higher the levels of meaning in life get. Zautra (2014) believes that research on resilience makes the mistake of ignoring its relevance to social interaction when it only emphasizes inner strength. The author claims that resilience is based on social connections, both in an individual and social sense. After trauma, while individuals develop resiliency, they become more open to social interactions. social interactions also help to develop resiliency. There is a two way process between resiliency and social interactions according to the author. Furthermore, Cook and Bickman (1990) point out that the social support system is not effective in helping people overcome psychological symptoms of traumatic events immediately after they happen, but social relationships can ease such symptoms within an intermediate period, which supports the findings of the current research. This means that the person needs time to recover and find inner strength after a traumatic event. Without activating inner strength, social support cannot help people after trauma. In addition, their study has revealed that while belongingness and tangible support are effective in reducing psychological symptoms such as depression and anxiety, appraisal support is only effective in reducing anxiety after a certain time following a trauma. When the scale used in the current research is considered, it can be said that the items included both relationship and intimacy sub-dimensions are relevant to belongingness; this explains the impact of social relationships and support as a result of intimacy on meaning in the lives of people with high resilience scores.

Self-transcendence also mediates the relationship between resilience and meaning in life. Selftranscendence, as a feature of developmental maturation, reflects individuals' desire to head to something beyond themselves such as using any barrier in accordance with their inner potential, philosophy, dreams and values, their having satisfactory relationships with others, or combining today with the past which is meaningful for that particular moment, and so on (Frankl, 2004; Reed, 2008; Yalom, 1980). Research that suggests a positive relationship between resilience and self-transcendence can also be found in the literature (i.e. Kim, Lee \& Lee 2013). Connections among the concepts of resilience, meaning in life, self-transcendence, as well as their relationship with inner strength have been pointed out by many researchers (Nygren et al., 2010). Resilient individual gives up focusing on negative fate of her/himself. When s/he changes the focus and tends to concentrate upon another aim or life event, new aims create selftranscendence. Those who are resilient can get self-transcendence while they are coping with difficulties in life and thanks to their increased awareness they may become people who have high meaning in life.

Moreover, fairness mediates the relationship between resilience and meaning in life. Among individuals who are resilient, fairness is effective on the sense of meaning in life. It can be said 
that when individuals live a difficult life event and can be successful about becoming resilient, their assessment regarding life events changes in the same direction and their perception of justice becomes stronger. One study has demonstrated that lower levels of fairness and meaning in life are associated with lower levels of self-transcendence (Testoni et al., 2017). For instance, Krok (2016) has mentioned that while firefighters, who are less emotionally exhausted as well as having such feelings as personal achievement, competence, and proficiency at work, have a distinct source of personal meaning, such as justice in world, they have a sense of meaning in life too. In addition, Witvliet et al. (2008), in their study including participants with experiences in robbery, argued that negative emotions and the willingness to unforgive reduce when punitive or restorative justice is imagined. Based on this information, it can be concluded that traumatic events reveal justice demand. When the person starts to gain resiliency, s/he can start to see the event from another perspective. If justice criterion is met, the person can find meaning more easily.

\section{Limitations and Implications}

Considering the results of this study, it can be said to have several limitations. Within the frame of these limitations, a number of recommendations may be made for future research. The findings of this study are limited to the results obtained through self-reporting scales. Selfreporting assessment causes a tendency towards being defensive and presenting oneself good, so there may be bias in answers given to questions. At the same time the resilience scale used in the study assesses one perspective of resiliency but other resilience scales may show different findings. Future research can collect data using another scale. Still, this research is believed to be contributing to the literature by demonstrating the role of personal meaning in the relationship between resilience and meaning in life among university students. Second, the data for the dependent and independent variables has been collected from a single source in this study. According to Podsakoff, MacKenzie, Lee and Podsakoff (2003) and Antonakis, Bendahan, Jacquart and Lalive (2010), collecting data about dependent and independent variables from the same source (only from a participant) can cause variance deviation error. Therefore, in order to reduce the negative effects of variance deviation error, the distinctiveness of all measurements in the study has been tested. In addition, due to the nature of cross-sectional design, no causation can be claimed off the results in this study. At the same time cross-sectional method does not give information about participants' growth during time, like longitudinal method can determine. Therefore, a longitudinal research can be designed to prove causation and to see growth in time. In the research design, three variables were taken into consideration, but additional variables were not considered like latent variables. Future researchcan handle and control latent variables. Finally, the data collected in this study can guide experts to develop and apply a guidance and counseling program in accordance with the characteristics of personal meaning profile (achievement, relationship, self-transcendence, self-acceptance, intimacy and fairness) that university youth can use to cope with difficulties.

\section{Conclusion}

Based on all discussions above, it can be said that the findings of the current research and the model established considering the Logotherapy have been confirmed by the study. In this respect, this supports the view that changing a person's attitude and directing his/her spiritual energy to find meaning in life are Logotherapeutic responses to pain. In summary, it can be said that individuals who have a higher level of resilience have a sense of meaning in life when they have a goal that makes them exhibit an attitude towards life. 


\section{Conflict of interest}

The authors declare that they have no conflict of interest.

\section{Ethical Approval}

The study was approved by Istanbul Medipol University Ethical Committee (no: 108400987-245) as suitable for ethical rules. While data were collected, adult sample participated voluntarily and anonymously, and participants filled the consent form.

\section{Note}

This study was presented as oral presentation at the IIIrd International Eurasian Educational Research Congress.

\section{References}

Adler, A. (1962). What life should mean to you. London: George Allen \& Unwin.

Akbulut, Y. (2010). SPSS applications in social sciences. Istanbul: Ideal Culture Publishing.

Akın, A., Düşünceli, B., \& Çolak T.S. (2016). Personal Meaning Profile: Validity and reliability study. Journal of Educational Theory and Practice Research, 2(2), 12-19. http://static.dergipark.org.tr/article-download/34eb/ed81/f5b1/imp-JA52HG32TV$0 . p d f$ ?

Ameli, M., \& Dattilio, F. M. (2013).Enhancing Cognitive Behavior Therapy with Logotherapy: Techniques for clinical practice. Psychotherapy, 50(3), 387-391.DOI: $10.1037 / \mathrm{a} 0033394$.

Antonakis, J., Bendahan, S., Jacquart, P., \& Lalive, R. (2010). On making causal claims: A review and recommendations. The Leadership Quarterly, 21(6), 1086-1120. https://doi.org/10.1016/j.leaqua.2010.10.010

Arnett, J.J. (2007). Emerging adulthood: What is it, and what is it good for. Society for Research Child Development, 1(2), 68-73. DOI: 10.1111/j.1750-8606.2007.00016.x

Baessler, J., \& Oerter, R. (2003). Aspects of meaning of life in different subculture in Peru. Psychological Reports, 92, 1119-1130. OI: 10.2466/pr0.2003.92.3c.1119

Bandura, A. (1999). A social cognitive theory of personality. In L. Pervin \& O. John (Ed.), Handbook of personality (2nd ed., pp. 154-196). New York: Guilford Publications.

Bandura, A. (2010). Self-Efficacy. The Corsini Encyclopedia of Psychology. doi:10.1002/9780470479216.corpsy0836

Barber, B. K. (2008). Making sense and no sense of war: Issues of identity and meaning in adolescents' experience with political conflict. In B. K. Barber (Ed.), Adolescents and war: How youth deal with political violence. NY: Oxford University.

Batan, N., \& Ayten, A. (2015). A study on the relationship among psychological resilience, religious coping and life satisfaction. Religious sciences Journal, 15(3), 67-92.

Baumeister, R. F. (1991). Meanings of life. New York: Guilford Press. http://isamveri.org/pdfdrg/D03296/2015_3/2015_3_BATANSN_AYTENA.pdf

Brassai, L., Piko, B. F., \& Steger, M. F. (2011). Meaning in life: Is it a protective factor for adolescents' psychological health? International Journal of Behavioral Medicine, 18 (1), 44-51. DOI: 10.1007/s12529-010-9089-6

Budak, S. (2003). Dictionary of psychology. Ankara: Science and Art Publications.

Carrenon, D. F, Eisenbeck, N., Cangas, A. J., Garcia-Montes, J. M., Delvas, L.G., Maria, A. T. (2020). Spanish adaptation of the Personal Meaning Profile-Brief: Meaning in life, 
psychological well-being, and distress. International Journal of Clinical and Health Psychology. DOI: 10.1016/j.ijchp.2020.02.003

Cook, J.D., \& Bickman, L. (1990). Social support and psychological symptomatology following a netural disaster. Journal of Traumatic Stress, 3(4), 541-556. doi.org/10.1007/BF02039587

Davis, C.G., Nolen-Hoeksema, S., \& Larson, J. (1998). Making sense of loss and benefiting from the experience: Two construals of meaning. Journal of Personality and Social Psychology, 75, 561-574. DOI: 10.1037//0022-3514.75.2.561

Demirbaş, N. (2010). Meaning in life and ego-resilience]. (Unpublished Master Thesis). Hacettepe University Social Sciences. Ankara.

Emmons, R. A. (2002). Personal goals, life meaning and virtue: Wellsprings of a positive life. Personal goals, life meaning, and virtue: Wellsprings of a positive life. In. Keyes, Corey L. M.; Haidt, Jonathan, (2003). Flourishing: Positive psychology and the life well-lived, (pp. 105-128). Washington, DC, US: American Psychological Association,

Emmons, R. A. (2005). Striving for the sacred: Personal goals, life meaning and religion. Journal of Social Issues, 61(4), 731-745. http://www.psychology.hku.hk/ftbcstudies /refbase/docs/emmons/2005/56_Emmons2005.pdf

Erdoğan, E. (2015). The relationship of resilience with god perception forms, religion orientation and subjective religiousness: A sample of university students. Mustafa Kemal University Journal of Social Sciences Institute, 12 (29), 223-246. http://static.dergipark.org.tr/article-download/imported/5000103968/5000106041.pdf?

Evans, J. (2012). Philosophy for life. London, England: Ryder

Frankl, V. E. (1963). Man's search for meaning. New York: Pocket Books.

Frankl, V.E. (2004). Logos, Paradox, and search for meaning. In A. Freeman, M.J. Mahoney, P. Devito, D. Martin (Eds.), Cognition and Psychotherapy (second edition), (s.83100).NewYork: Springer Publishing.

Fry, P. S. (1998). The development of personal meaning and wisdom in adolescence: A reexamination of moderating and consolidating factors and influences. In P. T. P. Wong \& P. S. Fry (Eds.), The human quest for meaning (pp. 91-110). Mahwah, NJ: Erlbaum.

Graber, A. (2004). Viktor Frankl's Logotherapy: Method of choice in ecumenical pastoral psychology. USA: Wyndham Hall Press.

Grotberg, H. E. (2003). Resilience for today: Gaining strength from adversity. Westport, CT: Praeger Publishers.

Guttman, D. (2001). A Logotherapeutic Approach to the Quest for Meaningful Old Age. Journal of Religion \& Spirituality in Social Work: Social Thought, 20(3), 117-128. DOI: 10.1080/15426432.2001.9960298

Helgeson, V.S., Reynolds, K.A., \& Tomich, P.L. (2006). A meta-analytic review of benefit finding and growth. Journal of Consulting and Clinical Psychology, 74, 797-816. DOI: 10.1037/0022-006X.74.5.797

Heng, M.A., Fulmer, G.W., Blau, I. P. (2020). Youth purpose, meaning in life, social support and life satisfaction among adolescents in Singapore and Israel. Journal of Educational Change, 21, 299-322. https://doi.org/10.1007/s10833-020-09381-4

Iacoviello, B. M., Charney, D. S. (2020). Cognitive and behavioral components of resilience to stress. In A. Chen (Ed.), Stress Resilience (pp. 23-31). Cambridge: Academic Press

Janoff-Bulman, R., \& Frantz, C.M. (1997). The impact of trauma on meaning: From meaningless world to meaningful life. In M. Power \& C.R. Brewin (Eds.), The transformation of meaning in psychological therapies, (pp. 91-106). Chichester, England: Wiley

Jekielek, S., \& Brown B. (2005). The transition to adulthood: characteristics of young adults ages 18-24 in America. Baltimore, MD: Kids Count/PRB/Child T 
Joseph, S., \& Linley, P.A. (2005). Positive adjustment to threatening events: An organismic valuing theory of growth through adversity. Review of General Psychology, 9, 262-280. https://doi.org/10.1037/1089-2680.9.3.262

Kasen, S., Wickramaratne, P., Gameroff, M.J., \& Weissman (2011). Religiosity and resilience in persons at high risk for majör depression. Psychological Medicine, 42(3), 509-519. DOI: https://doi.org/10.1017/S0033291711001516

Kiang, L., \& Fuligni, A. J. (2010). Meaning in life as a mediator of ethnic identity and adjustment among adolescents from Latin, Asian, and European American backgrounds. Journal of Youth and Adolescence, 39, 1253-1264. doi: 10.1007/s10964009-9475-z

Kim, J.W., Lee, H.K.,\& Lee, K. (2013). Influence temperament and character on resilience. Comprehensive Psychiatry, 54(7), 1105-1110.doi.org/10.1016/j.comppsych.2013.0505

Kim, T., Lee, M. L., Yu, K., Lee, S., \& Puig, A. (2005). Hope and the meaning of life as influences on Korean adolescents' resilience: Implications for counselors. Asian Pacific Education Review, 6, 143-152. https://doi.org/10.1007/BF03026782

Kleber, R.J., \&Brom, D. (1992). Coping with trauma. Amsterdam: Swets \& Zeitlinger.

Krok, D. (2015). The role of meaning in life within the relations of religious coping and psychological well-being. Journal of Religion and Health, 54 (6), 2292-2308. doi: 10.1007/s10943-014-9983-3

Krok, D. (2016). Can meaning buffer work pressure? An exploratory study on styles of meaning in life and burnout in firefighters. Archives of Psychiatry and Psychotherapy, 1, 31-42. DOI: $10.12740 / \mathrm{APP} / 62154$

Lightsey, O. R. (2006). Resilience, Meaning, and Well-Being. The Counseling Psychologist, 34(1), 96-107. doi:10.1177/0011000005282369

Lin, A. (2001). Exploring sources of life meaning among Chinese. (Unpublished Master's thesis). Langley, Trinity Western University, Canada.

Lukas, E. (1986). Meaning in Suffering. California: Institute of Logotherapy Press.

Luthar, S. S., Cicchetti, D., \& Becker, B. (2000). Research on Resilience: Response to Commentaries. Child Development, 71(3), 573-575.

Maddi, S. R. (1970). The search for meaning. In M. Page (Ed.), Nebraska Symposium on Motivation (pp. 137-186). Lincoln: University of Nebraska Press

Marshall, M. (2009). Life with Meaning. Guide to the Fundamental Principles of Viktor E. Frankl's Logotherapy.www.maritimelogotherapy.org

Masten, A. S., \& Reed, M. G. J. (2002). Resilience in development. In C. R. Snyder \& S. J. Lopez (Eds.), Handbook of positive psychology. New York: Oxford University Press.

Masten, A. S., Cutuli, J., Herbers, J. E., \& Reed, M.G. (2009). Resilience in development. In S. J. Lopez \& C. R. Snyder (Eds.), Oxford handbook of positive psychology (2nd ed., pp. 117-148). New York: Oxford University Press.

Norman, E. (2000). Resiliency enhancement: Putting the strengths perspective into social work practice. New York: Columbia University Press

Nygren, B., Alex, L., Jonsen, E., Gustafson, Y., Norberg, A., \& Lundman, B. (2005). Resilience, sense of coherence, purpose in life and self-transcendence in relation to perceived physical and mental health among the oldest old. Aging \& Mental Health, 9(4), 354-362. DOI: 10.1080/1360500114415

O'Connor, M. F. (2003). Making meaning of life events: Theory, evidence, and research directions for an alternative model. Omega: Journal of Death and Dying, 46, 51-75. DOI: 10.2190/0CKD-PVQ0-T260-NTXU

Pan, J., Wong, D. F. K., Chan, C. L. W., \& Joubert, L. (2008). Meaning of life as a protective factor of positive affect in acculturation: A resilience framework and a cross-cultural 
comparison. International Journal of Intercultural Relations, 32(6), 505-514. https://doi.org/10.1016/j.ijintrel.2008.08.002

Pan, J.Y. (2011). A resilience-based and meaning-oriented model of acculturation: A sample of mainland Chinese postgraduate students in Hong Kong. International Journal of Intercultural Relations, 35(5), 592-603. https://doi.org/10.1016/j.ijintrel.2011.02.009

Park, C.L., Knott, C.L., Williams, R.M., Clark, E. M., Williams, B.R. \& Schukz, E. (2020). Meaning in Life Predicts Decreased Depressive Symptoms and Increased Positive Affect over Time but Does not Buffer Stress Effects in a National Sample of AfricanAmericans. Journal of Happiness Studies. https://doi.org/10.1007/s10902-019-00212-9

Podsakoff, P. M., MacKenzie, S. B., Lee, J. Y., \& Podsakoff, N. P. (2003). Common method biases in behavioral research: A critical review of the literature and recommended remedies. Journal of Applied Psychology, 88(5), 879. DOI: 10.1037/00219010.88.5.879

Rathi, N., \& Rastogi, R. (2007). Meaning in Life and Psychological well-being in preadolescents and adolescents. Journal of the Indian Academy of Applied Psychology, 33 (1), 31-38. http://medind.nic.in/jak/t07/i1/jakt07i1p31.pdf

Reed, P.G. (2008). Theory of self-transcendence. In M.J. Smith, P. Liehr (Eds.), Middle range theory for nursing (2nd ed.), (pp. 105-130). New York: Springer.

Reker, G. T., \& Wong. P. T. P. (1988). Aging as an individual process: Toward a theory of personal meaning. In J. E. Birren \& V. L. Bengston (Eds.), Emergent theories of aging (pp. 214-246). New York: Springer

Schnell, T., \& Becker, P. (2006). Personality and meaning in life. Personality and Individual Differences, 41(1), 117-129. doi:10.1016/j.paid.2005.11.030

Schok, M. L., Kleber, R. J., \& Lensvelt-Mulders, G. J.L.M. (2010). A model of resilience and meaning after military deployment: Personal resources in making sense of war and peacekeeping experiences. Aging \& Mental Health, 14(3), 328-338. DOI: 10.1080/13607860903228812

Sezer, S. (2012). A view to the subject of the meaning of life in terms of theoretical and psychometric studies. Journal of Faculty of Educational Sciences, 45 (1), 209-227. https://pdfs.semanticscholar.org/46b9/5ae10eba5208be683fcf8657dc260179b8d6.pdf

Steger, M. F., Frazier, P., Oishi, S., \& Kaler, M. (2006). The Meaning in life questionnaire: Assessing the presence of and search for meaning in life. Journal of Counseling Psychology, 53, 80-93. DOI: 10.1037/0022-0167.53.1.80

Taylor, S.E. (2003). Health psychology. New York: McGraw-Hill.

Tedeschi, R.G., \& Calhoun, L.G. (1996). The posttraumatic growth inventory: Measuring the positive legacy of trauma. Journal of Traumatic Stress, 9, 455-471. https://doi.org/10.1002/jts.2490090305

Terzi, Ş. (2006). Adaptation of Resilience Scale (RS) to the Turk culture: It's reliability and validity. Turkish Psychological Counseling and Guidance Journal, 3(26), 77-86. http://static.dergipark.org.tr/article-download/imported/1058000148/1058000150.pdf?

Testoni, I., Sansonetto, G., Ronconi, L., Rodelli,M., Baracco, G., \& Grassi, L. (2017). Meaning of life, representation of death, and their association with psychological distress. Palliative and Supportive Care, 1-9. doi:10.1017/S1478951517000669

Thompson, S. C., \& Janigian, A. S. (1988). Life schemes: a framework for understanding the search for meaning. Journal of Social and Clinical Psychology, 7, 260-280. https://guilfordjournals.com/doi/pdfplus/10.1521/jscp.1988.7.2-3.260

Uysal, V., Göktepe, A.K., Karagöz, S., \& İlerisoy, M. (2017). A research about the relationships and interactions between religious coping, hope, life satisfaction and psychological resilience. Marmara University Faculty of Theology Journal, 52, 139-160. DOI: 10.15370/maruifd.333535 
Wagnild, G.M, \&Young, H.M. (1993). Development and psychometric evaluation of the Resilience Scale. Journal of Nursing Measurement 1(2), 165-178.

Wexler, L. M., DiFluvio, G., \& Burke, T. K. (2009). Resilience and marginalized youth: Making a case for personal and collective meaning-making as part of resilience research in public health. Social Science \& Medicine, 69, 565-570. DOI: 10.1016/j.socscimed.2009.06.022

Witvliet, C.V.O., Worthington, E.L., Jr., Root, L.M., Sato, A.F., Ludwig, T.E., \& Exline, J.J. (2008). Retributive justice, restorative justice, and forgiveness: An experimental psychophysiology analysis. Journal of Experimental Social Psychology y, 44, 10-25. https://doi.org/10.1016/j.jesp.2007.01.009

Wong, P. T. P. (1998). Implicit theories of meaningful life and the development of the Personal Meaning Profile (PMP). In P.T.P. Wong \& P.S. Fry (Eds.), The human quest for meaning: A handbook of psychological research and clinical applications. Mahwah, NJ: Erlbaum.

Wong, P. T. P., \& Wong, L. C. J. (2012). A meaning-centered approach to building youth resilience. In P. T. P. Wong (Ed.), Personality and clinical psychology series. The human quest for meaning: Theories, research, and applications (pp. 585-616). New York, NY, US: Routledge/Taylor \& Francis Group.

Wong, P.T.P. (1989). Personal meaning and successful aging. Canadian Psychology, 30 (3), 516-525. https://doi.org/10.1037/h0079829

Wong, P.T.P. (1997). Meaning-centered counseling: A cognitive behavioral approach to logotherapy. The International Forum for Logotherapy, 20, 85-94. https://www.researchgate.net/publication/308052294_Meaningcentered_counseling_A_cognitivebehavioral_approach_to_logotherapy

Yalom, I. D. (1980). Existential psychotherapy. New York: Basic Books.

Zautra, A.J.. (2014). Resilience is social, after all. In Kent, M, Davis, M.C., \& Reich, J.W. (2014). Handbook of Resilience Approaches to Stress and Trauma (pp. 185-196). New York: Rutledge.

Zeleskov-Doric, J., Hedrih, V., \& Doric, P (2012). Relations of resilience and personal meaning with vicarious traumatization in psychotherapists. International Journal of Psychotherapy, 16 (3), 44-55. 